Weronika Kosmalska

Uniwersytet im. Adama Mickiewicza w Poznaniu

\title{
KONWENCJA EPISTOLOGRAFICZNA I BEZPOŚREDNIOŚĆ WYRAZU W LISTACH JANA III SOBIESKIEGO DO MARYSIEŃKI
}

Mówi się, że nie powinno się czytać cudzej korespondencji. Jest ona zbyt prywatna, intymna, gdyż skierowana do określonego adresata. Dodatkowo może poruszać tematy głęboko osobiste. Szanujemy to, zgadzamy się na tę formę prywatności, raczej nie kwestionujemy zasadności owego niepisanego prawa. Ale czy na pewno?

List jako forma komunikowania się istnieje od wieków. Interesujące są jego objaśnienia znaczeniowe. Słownik terminów literackich podaje definicję listu jako wypowiedzi pisemnej, która skierowana jest do określonego adresata i ma na celu powiadomienie go o czymś lub nakłonienie do jakiegoś zachowania ${ }^{1}$. Według teorii Stefanii Skwarczyńskiej jest to twór językowy charakteryzowany przez przynależność do swoistej hierarchii struktur, która na każdym z trzech stopni determinowana jest przez inny czynnik. Mamy zatem do czynienia ze „strukturą sensownego aktu porozumienia międzyludzkiego”, „strukturą komunikatu językowego” oraz „strukturą rodzaju literackiego”, której istotnymi wyznacznikami są funkcje komunikatu².

Co ciekawe, definicja ta do tego momentu nie ujmuje jakże istotnego współcześnie podziału, a mianowicie rozróżnienia listów auten-

1 Zob. J. Sławiński, List, w: M. Głowiński, T. Kostkiewiczowa, A. Okopień-Sławińska, J. Sławiński, Słownik terminów literackich, Wrocław 1982.

2 Zob. S. Skwarczyńska, Wstęp do nauki o literaturze, t. 3, Warszawa 1965, s. 72-115. 
tycznych, pisanych przez realnie istniejące osoby, od fikcyjnych, tworzonych z ukierunkowaniem na ich literackość. Tutaj warto nadmienić, że Skwarczyńska rozbudowuje jednak swą definicję listu, doprecyzowując owe funkcje komunikatu jako „kierunek działania komunikatu ze względu na określony cel”. Ze względu na skuteczność kształtują się listy o orientacji praktycznej (skuteczności natychmiastowej) oraz humanistycznej (skuteczności długodystansowej) ${ }^{3}$.

Doprecyzowania owych rozróżnień podjął się Stanisław Dąbrowski, który orientacji praktycznej przyporządkował skuteczność doraźną, a humanistycznej - trwałą ${ }^{4}$. Przedstawiony dychotomiczny podział, choć nie ma na celu wyznaczenia wyraźnej granicy między autentycznością a fikcją, pozwala już na tym poziomie odkryć genezę listów przyporządkowanych do obu kategorii. Łatwo bowiem zauważyć, że „praktyczność” Skwarczyńskiej znajduje idealne odzwierciedlenie w listach autentycznych, natomiast zwrot ku charakterowi humanistycznemu wpasowuje się w fikcję i związane z nią przeznaczenie literackie.

Po przedstawieniu powyższego podziału należy jeszcze raz wrócić do kwestii czytania korespondencji. Listy fikcyjne tworzone są z myślą o szerokim gronie odbiorców i powszechnej dostępności. Lokuje się je w granicach sztuki, podkreślając ich literackość. Ich czytanie nie stanowi przedmiotu dyskusji. Inaczej sprawa się ma z listami autentycznymi: mimo deklarowanego szacunku do cudzej prywatności w księgarniach znajdziemy liczne wydania osobistej korespondencji, przeznaczonej do publicznego użytku - co prawda zazwyczaj dopiero po śmierci ich autorów. Skwarczyńska pisze:

List jest cząstką życia. Powstaje na płaszczyźnie życia, w bezpośrednim z nim związku. (...) List na tle życia nie jest celem, lecz środkiem. (...) może być wyraźnym fragmentem życia, aktem życia. (...) Współrzędność listu względem życia lub jego z nim bezpośredni związek jako cząstki

3 Zob. S. Skwarczyńska, Wstęp do nauki..., s. 98.

${ }^{4}$ Zob. M. Ryszkiewicz, List $w$, interesownej" $i$ "nieinteresownej” odmianie dzieła literackiego, „Annales UMCS” XXII (2004) sectio FF, s. 47-64. 
z całością - jest istotą charakteru listu. Nie ma prawdziwego listu pozbawionego tego podstawowego związku z życiem ${ }^{5}$.

Może właśnie fakt, że zbiory listów przetrwały wiele lat i są świadectwem czyjegoś życia, powoduje, że tę korespondencję czyta się z zapartym tchem, z wypiekami na twarzy i przyspieszonym pulsem. A jeśli dołączymy do powyższych informacji popularność autora, bycie postacią historyczną, wówczas słowa przez niego kreślone (nierzadko w pośpiechu) stają się jeszcze ciekawsze.

Tak właśnie jest z listami króla Jana III Sobieskiego do żony Marii Kazimiery, która dla niego na zawsze pozostała „Marysieńką”, drobną Francuzeczką, w której zakochał się dwudziestosześcioletni wówczas kawaler, gdy zobaczył ją w roku 1655 na dworze królowej Ludwiki Marii ${ }^{6}$. Ich korespondencja jest fenomenalnym źródłem informacji historycznych z burzliwego okresu w dziejach Rzeczypospolitej - zapisem gloryfikowanych zwycięstw i hańbiących porażek, politycznych podchodów i knowań podczas nieustających elekcji. Ale to przecież nie wszystko. Listy te przede wszystkim ukazują inną twarz gromowładnego zwycięzcy spod Wiednia: twarz kochanka, umartwionego Celadona dręczonego przez piękną Astreę, zatroskane oblicze gospodarza, męża, później także ojca, który nigdy nie zapomni dodać: „dzieci całuję i obłapiam”7 . Świadomość, że pożółkły ze starości papier i wyblakłe litery przekazują autentyczne wydarzenia - są zapisem miłości, rozpaczy, gniewu czy wzruszeń - sprawiła, że korespondencja państwa Sobieskich tak szybko zyskała na popularności.

Nie ma wątpliwości co do tego, że epistoły pisane przez Sobieskiego znajdują miejsce wśród listów miłosnych. Wskazuje na to nie tylko adresat, ale także - a może przede wszystkim - tematyka poruszana przez Jana. Ryszard Ganszyniec pisze: „Listem miłosnym oznaczamy zwykle to wszystko, co w motywach swych i formach podyktowane

\footnotetext{
${ }^{5}$ S. Skwarczyńska, Teoria listu, Lwów 1937, s. 332-335.

6 Zb. T. Boy-Żeleński, Marysieńka Sobieska, Warszawa 1976, s. 34.

${ }^{7}$ J. Sobieski, Listy do Marysieńki, red. L. Kukulski, Warszawa 1970, s. 592.
} 
jest miłością, uczuciowo albo też prawnie znajduje się w granicach miłości (...)”. Gdyby zatrzymać się tutaj, listem miłosnym nazywalibyśmy te pisma, które zwyczajnie traktują o uczuciu. Jednak Ganszyniec uzupełnia ową definicję o miłość prawną, małżeńską, która jako jedyna znajduje uznanie „wskutek ciasnoty naszych poglądów prawnych i społecznych" .

Trzeba jednak nieco zweryfikować powyższe dopowiedzenie, biorąc pod uwagę fakt, że Polskie listy miłosne dawnych czasów zostały wydane w roku 1925. Minął prawie wiek i społeczne opinie dotyczące miłości są daleko bardziej swobodne, niż były w dwudziestoleciu międzywojennym. Mimo że Listy do Marysieńki obejmują wyłącznie korespondencję małżeńską, myślę, że współcześnie słuszne będzie zatrzymanie się na pierwszej części definicji. By udowodnić miłosną tematykę listów wystarczy przywołać kilka fragmentów z obszernej korespondencji Sobieskich. W ten sposób Jan rozpoczyna np. list do żony pisany ze Lwowa, datowany na 16 kwietnia 1665 roku:

Gdyby nie co dzień, ale co moment tak pewne do pisania zdarzały się okazje, miałbym się za najszczęśliwszego na świecie człowieka, tak to jest rzecz miła pisać przynajmniej, kiedy wiedzieć nie można temu, który wszystkie swoje gusty i plezyry w jasności swojej najśliczniejszej utopił Jutrzenki ${ }^{10}$.

W słowach Sobieskiego niewątpliwie pobrzmiewa uwielbienie Marysieńki jako źródła jego życia, zdrowia, szczęścia. Niesamowite, jak ten barczysty Polonus z krwi i kości potrafił pisać do damy swego serca, jak głębokie uczucie przebija przez te kilka słów. Inny fragment, tym razem z 31 października tego samego roku, kreślony w Brześciu:

\footnotetext{
8 R. Ganszyniec, Polskie listy miłosne dawnych czasów, Kraków 1925, s. 15.

9 R. Ganszyniec, Polskie listy..., s. 15.

${ }^{10}$ J. Sobieski, Listy do Marysieńki, s. 34.
} 
Teraz obłapiając, całując milion na minutę godziny razów wszystkie jej śliczności, jako dawnej swej pani i dobrodziejki i bez żadnej różności, tym zostaję, co i był, to jest najwierniejszym sługą ${ }^{11}$.

Jaka poetyckość przebija przez prostotę i zwięzłość! Sobieski niekwestionowanie był mistrzem lakonicznej wypowiedzi; potrafił w kilku słowach oddać całe swoje uczucia.

Tak Tadeusz Boy-Żeleński pisze o stylu listów „Jachniczka”:

Zazwyczaj w listach styl jego nosi znamiona epoki: ciężki, z łacińska zawijany, odświętny i makaroniczny. Do niej - jakby inny człowiek pisał: myśl wyraża się swobodnie, bezpośrednio, z wzruszającą szczerością, znajdując wyraz dla subtelności bardzo na tle ówczesnej sarmackiej Polski egzotycznych ${ }^{12}$.

Fascynujące, jak trafnie Boy-Żeleński potrafił uchwycić tę różnicę. Ciężkość połączona z licznymi łacińskimi makaronizmami jest jakby wrośnięta w tego niepoprawnego Sarmatę, który mimo swej dwornej edukacji odebranej podczas zagranicznych wojaży oraz uzyskanej od wychowywanej na dworze królowej Francuzki Marysieńki ${ }^{13}$ na zawsze pozostał „najczystszym typem Polonusa”" ${ }^{14}$; nawet zewnętrznie, gdyż nigdy nie zrezygnował ze stroju szlacheckiego i szabli. Ona natomiast, mimo że od czwartego roku życia mieszkała w Polsce, do końca pozostała Francuzką. „Odbija się to i w charakterze ich listów” - podkreśla Boy-Żeleński w Marysieńce Sobieskiej. I ma absolutną rację - ona pisuje po francusku, czasem tylko, by być dosadniejszą, używa polszczyzny (mocno zresztą okaleczonej); on pisze po polsku, wtrącając czasem zamiast zwrotów łacińskich fragmenty francuszczyzny.

\footnotetext{
${ }^{11}$ J. Sobieski, Listy do Marysieńki, s. 90.

12 T. Boy-Żeleński, Marysieńka Sobieska, s. 21.

${ }^{13}$ Zob. C. Hernas, Barok, Warszawa 1973, s. 439.

${ }^{14}$ T. Boy-Żeleński, Marysieńka Sobieska, s. 22.
} 
Skwarczyńska zwraca uwagę na inny aspekt wypowiedzi Sobieskiego, a mianowicie na umiejętność prostego wyrażania rzeczy z natury swej wielkich:

A mówiąc o niej, o swojej miłości, daje jej dokładny wyraz, bez niedomówień i, jak potwierdza historia, bez przesad. Określa ją w kierunku intensywności i w kierunku odcieni jakościowych. Staje nam ona z listów Sobieskiego w całej swej dynamice, skondensowana, zagęszczona i w całej palecie barw ${ }^{15}$.

W tym miejscu należy jednak podać pewną informację, na którą zwraca uwagę Alojzy Sajkowski, a mianowicie że: „zarówno językoznawca, jak i historyk literatury sygnalizują zjawisko oczywiste - epistolografia staropolska znana jest w sposób niezadowalający i ułamkowy"16. Również czytając listy Sobieskiego do małżonki, trzeba mieć świadomość, że jest to korespondencja niepełna, często pozbawiona obszerniejszych fragmentów, poddana cenzurze w wyniku dokonania (lub zlecenia dokonania) odpisu oryginału przez Jerzego Samuela Bandkiego na przełomie XVIII i XIX wieku. Bandkie zajął się korespondencją Sobieskich jako historyk, dlatego też nierzadko urywał pracę nad danym listem, zaznaczając, że ciąg dalszy zawiera wyłącznie uniesienia miłosne $^{17}$. Jakże wiele epistolografia ta straciła, gdy została pozbawiona najintymniejszych fragmentów, ukazujących ściśle prywatne oblicze króla, jawiącego się dla większości jako ten, który „miał wąsy i bił Turków"! ${ }^{18}$ Mimo to nadal dysponujemy pokaźnym zbiorem jego pism. Listy do Marysieńki, obejmujące teksty z lat 1655-1683, zajmują blisko 600 stron! Ale cóż się dziwić, skoro Celadon w jednym z listów wy-

15 S. Skwarczyńska, Listy Sobieskiego do Marysieńki jako zjawisko kulturalne i literackie, „Ruch Literacki” 11 (1936), s. 41.

${ }^{16}$ A. Sajkowski, Sarmackie tradycje i europejskie horyzonty, Poznań 2007, s. 155.

17 Zob. A. Sajkowski, Staropolska miłość. Z dawnych listów i pamiętników, Poznań 1981, s. 153.

18 T. Boy-Żeleński, Marysieńka Sobieska, s. 21. 
znaje: „Nie co dzień, ale co minuta rad bym się pytał o zdrowiu twoim, moja śliczna panno (...)"19. Tu znów Sobieski w kilku prostych, bezpośrednich ${ }^{20}$ słowach z całą mocą oddaje siłę swego uczucia, które (nie ma wątpliwości) stało się wyznacznikiem jego epistoł jako miłosnych.

Jednak czy określenie epistolografii Jana Sobieskiego jako „listów miłosnych" w pełni wyczerpuje potencjał owych tekstów? Ganszyniec dokonuje dalszego podziału listów na listy zakochanego mężczyzny z odpowiedziami na nie, listy oświadczynowe niewiast z odpowiedziami na nie, listy narzeczonych, listy małżonków oraz listy dla odnowienia miłości ${ }^{21}$. Zastanawiające jest jednak rozróżnienie listów zakochanego mężczyzny oraz listów małżonków. Czy taki podział nie sugeruje bowiem, że miłość małżeńska nie jest tym żarliwym uczuciem, jakim darzy swą wybrankę kochanek? Czy nie sytuuje uczucia kochanka ponad siłą miłości małżeńskiej? Owszem, pisze o tym Ganszyniec w dalszej części swej pracy: „Listy małżeńskie są już innego rodzaju. Tchną uczuciem zaspokojonej miłości, wolnej od trosk i trwogi, pozbawionej wzlotów i drżeń serca w uczucie przemienionego" ${ }^{22}$. Zdaje się jednak, że Sobieski wyłamuje się z tej klasyfikacji, jakby na zawsze pozostał młodzieńcem namiętnie kochającym swą Astreę. Ganszyniec kontynuuje: „(...) człowiek w całem swem życiu jeden tylko właściwy list miłosny pisze, mianowicie pierwszy list, który, wybuchając na kształt wulkanu z zamętu zmysłów, radości i męki serca, błaga o wzajemną miłość" ${ }^{23}$. Sobieski nigdy nie skończył tego swojego pierwszego listu, każdy kolejny jest skarbcem nowych uczuć, nowej żarliwości i namiętności. Doprawdy, nigdy nie przestał kochać swej Francuzki. Mimo - a może przez to - że umiała ona być zmienną, zawsze trzymała go w niepewności swego uczucia, droczyła się z nim, pozwalała sobie na nie lada oskarżenia i zachcianki.

${ }^{19}$ J. Sobieski, Listy do Marysieńki, s. 48.

20 „Bezpośredniość - bycie niekonwencjonalnym, szczerym, prostym” - Praktyczny słownik wspótczesnej polszczyzny, t. 11, red. H. Zgółkowa, Poznań 1997.

${ }^{21}$ Zob. R. Ganszyniec, Polskie listy..., s. 2.

${ }^{22}$ R. Ganszyniec, Polskie listy..., s. 4.

${ }^{23}$ R. Ganszyniec, Polskie listy..., s. 2. 
„Kiedy jemu tu serce rwie się z miłości, ona się mizdrzy i pisze, aby ją «kochał tak jako la palatine de Sandomir ${ }^{24}{ }{ }^{25}$. Być może dlatego Sobieski nigdy nie zmienił swych listów w „małżeńskie” ${ }^{26}$ - on po prostu nigdy nie poczuł zaspokojenia swej miłości, bezpieczeństwa, nigdy nie był pewny uczuć Marysieńki.

Tak rozpoczyna się pierwszy list znajdujący się w zbiorze opracowanym przez Leszka Kukulskiego:

Tak mi się twoja śliczność, moja złota panno, wbiła w głowę, że zawrzeć oczu całej nie mogłem nocy. (...) Owo widzę, że mię twoje wdzięczne tak oczarowały oczy, że bez nich i momentu wytrwać będzie niepodobna. (...) To jest pewna, że już od dawnego czasu zdało mi się, żem bardziej i więcej kochać nie mógł, ale teraz przyznawam, że lubo nie bardziej, bo niepodobna kochać bardziej, ale je vous admire coraz więcej ${ }^{27}$.

Początkujący mąż ewidentnie jest oczarowany swą młodą żoną, list jest bowiem datowany na 9 czerwca 1655 roku, podczas gdy nieoficjalny ślub chorążego Sobieskiego z wdową po wojewodzie Zamoyskim odbył się w maju tegoż roku, a oficjalny 6 lipca ${ }^{28}$. Ów nieoficjalny ślub był wyrazem przebiegłości tej, na której młoda Marysieńka się wzorowała. Ówczesna królowa Ludwika Maria przyłapała „żałobną wdówkę na schadzce z rycerzem" tuż po śmierci pierwszego męża

24 „Wojewodzinę sandomierską” - Marysieńka życzy sobie, aby Sobieski kochał ją tak, jakby nadal była żoną Jana Zamoyskiego.

${ }^{25}$ T. Boy-Żeleński, Marysieńka Sobieska, s. 124.

${ }^{26}$ „(...) tam miłości między małżeństwem nie znają - i szkoda tam jeździć, żeby się zaś nie zapowietrzyć. Bo powiadają, że apres la jouissance de la pesonne almee zaraz się amour obraca en amitie i dlatego każdy tam mąż ma swoją maitresse. U nas zaś stara w miłości moda: im się lepiej znają, tem się w sobie bardziej kochają. Tam zaś tak często w amorach się odmienia jako w karetach moda" - J. Sobieski, Listy do Marysieńki, s. 313. Sobieski swoją opinię na temat miłości we Francji przedstawił w powyższym fragmencie listu. Sam pozostał wierny polskiej miłości małżeńskiej.

${ }^{27}$ J. Sobieski, Listy do Marysieńki, s. 28.

${ }^{28}$ Zob. T. Boy-Żeleński, Marysieńka Sobieska, s. 90-91. 
Marii Kazimiery - Jana Zamoyskiego - i nie wahała się złączyć małżeńskim węzłem młodych kochanków ${ }^{29}$.

Dla pokazania trwałości Sylwandrowych zaklęć warto zwrócić uwagę na list pisany z Żurawna dwadzieścia jeden lat po ślubie:

\begin{abstract}
Ja, za łaską bożą, zdrówem jeszcze, choć równa tej pracy, nie wiem, jeżeli kiedy była. Ale cóż mi po nim jest, jeśli nie usłyszę, a prędko, o polepszeniu tego, które sobie mam milion razy za droższe nad swoje i bez którego żyć i momentu jednego nie chcę i nie pragnę? Całuję zatem wszystkie śliczności i ściskam z duszy Wci serca mego jedynego ${ }^{30}$.
\end{abstract}

Oprócz charakterystycznej dla pisma Sobieskiego bezpośredniości łatwo dostrzec żar owych wypowiedzi. „Jachniczek” pozostaje w roli kochanka, jego listy niezmiennie utrzymane są w konwencji listu miłosnego, listu pisanego przez zakochanego mężczyznę. Miłość do tego stopnia stoi na pierwszym planie, że przesiąknięte nią są wszystkie inne przeżycia Sobieskiego, jego kampanie wojenne, lektura, polity$\mathrm{ka}^{31}$. Zdaje się, że właśnie owo uczucie jest źródłem wszelkich decyzji w życiu króla - atmosfera głębokiej namiętności nie opuszcza go nawet w obozach czy na polowaniach. „On ją kochał krwiście i do zgłupienia” - pisze Ludwik Stomma ${ }^{32}$. Podkreśla przy tym przebiegłość tej niepozornej Francuzki: „Pan zawierzył sentymentom - ona kwestii kapitalistycznego zysku" - kontynuuje, zwracając się do Jana Sobieskiego ${ }^{33}$. „Wszyscy przegrani? - I to właśnie nieprawda. My wiemy, królu Janie, ile miłość znaczy. I niech będzie nawet bolesna (...)" - dodaje autor, kończąc rozdział o życiu seksualnym Jana III Sobieskiego ${ }^{34}$. Przy wielu błędach Sobieskiego, przy niewielkiej sympatii do Marii Ludwiki -

${ }^{29}$ Zob. W. Konopczyński, Od Sobieskiego do Kościuszki, Kraków 1921, s. 77-78.

${ }^{30}$ J. Sobieski, Listy do Marysieńki, s. 476.

31 Zob. S. Skwarczyńska, Listy Sobieskiego..., s. 45.

${ }^{32}$ Zob. L. Stomma, Życie seksualne królów Polski i inne smakowitości, Warszawa 2002, s. 70 .

${ }^{33}$ Zob. L. Stomma, Życie seksualne..., s. 70.

${ }^{34}$ Zob. L. Stomma, Życie seksualne..., s. 70. 
warto pamiętać, że to dzięki niej można dziś bliżej poznać wąsatego zwycięzcę spod Wiednia, Chocimia, Podhajec.

Pozostając w konwencji listu miłosnego męża kochanka do małżonki, warto zwrócić uwagę, w jaki sposób Sobieski zwracał się do swej żony. Znamienny jest już sam tytuł zbioru listów króla, sugeruje bowiem, że adresatką nie była żona, Maria Kazimiera d’Arquien, ale Marysieńka. Polskie zdrobnienie wskazuje na stosunek Sobieskiego do ukochanej, odkrywa domowe, prywatne kulisy burzliwego życia chorążego, hetmana, króla ${ }^{35}$. Dla niego nielubiana w Rzeczypospolitej stronniczka Kondeusza była Marysieńką, piękną, dobrą, umiłowaną, znajdującą się wręcz w tajemniczej sferze sacrum. Dominantę stanowi tu familiarność, czyli odrzucenie konwenansu towarzyskiego, bezpośredniość i serdeczność, w przeciwieństwie do charakteru oficjalnego, ceremonialności czy oschłości ${ }^{36}$. Wystarczy spojrzeć na zwroty adresatywne używane przez Sobieskiego: „Najśliczniejsza i najukochańsza duszy i serca pociecho!”37, „Jedyne duszy kochanie, najśliczniejszy serca panie!” , „Najukochańsza i jedyna serca i duszy pociecho, najśliczniejsza Marysieńku!"”, , „Jedyna duszy, serca i wszystkich pociech pani i dobrodziejko, najśliczniejsza i najwdzięczniejsza Marysieńku!" ${ }^{40}$. Czuć serdeczność w tych zwrotach, pewną czułość, tkliwość. Sobieski z tęsknotą pisze do swej ukochanej żony, starając się w każdym fragmencie tekstu udowodnić, jak wiele dla niego znaczy. Nierzadko oddaje w jej ręce swoją przyszłość, dając jej carte blanche ${ }^{41}$.

Używanie wielobarwnych środków językowych przez Sobieskiego oddaje klimat, atmosferę towarzyszącą tej szalonej miłości po grób.

35 „Dramatyczność listu będzie na ogół tym żywsza, im żywszy będzie kontakt ży c i ow y obu adres a tów” - cyt. za: S. Skwarczyńska, Teoria listu, s. 336.

${ }^{36}$ Zob. H. Wiśniewska, Zachowania grzecznościowe w listach rodzinnych Ignacego Krasickiego, „Pamiętnik Literacki” 91 (200o) z. 3, s. 161.

${ }^{37}$ J. Sobieski, Listy do Marysieńki, s. 29.

${ }^{38}$ J. Sobieski, Listy do Marysieńki, s. 76.

39 J. Sobieski, Listy do Marysieńki, s. 132.

${ }^{40}$ J. Sobieski, Listy do Marysieńki, s. 272.

${ }^{41}$ Zob. T. Boy-Żeleński, Marysieńka Sobieska, s. 126-134. 
Kochający mąż w każdym ze zwrotów adresatywnych używa przymiotników dookreślających ową Marysieńkę. Warto zwrócić uwagę, jakie to są przymiotniki, nie wystarczyło bowiem Sobieskiemu, że mają wartość dodatnią, wydźwięk pozytywny. On ucieka się do stopnia najwyższego, i tak powstaje: „najpiękniejsza”, „najśliczniejsza”, „najukochańsza”, co daje wrażenie absolutnego i bezwarunkowego uwielbienia, które potęgowane jest przez wyliczenie tych wyrażeń obok siebie. Dodatkowo Sobieski w sposób bezpośredni, a jednak z nutą artyzmu, wyraża, kim jest dla niego Marysieńka. Powstają zatem sformułowania: „duszy i serca pociecho”, „serca panie”, „dobrodziejko". Nawiązując do serca symbolizującego życie, wszelkie uczucia, a przede wszystkim miłość, oraz do duszy - symbolu życia wiecznego, łącznika z Bogiem - Sobieski pisze najgłębsze, najbardziej wzruszające wyznanie miłości, oddając się całkowicie w ręce uwielbianej kobiety. Robi to bez patosu, zbędnych słów czy porównań. Jest na wskroś bezpośredni, prostolinijny, szczery. Dodanie do powyższych sformułowań określenia „jedyna" tworzy kompletny obraz mężczyzny do głębi wiernego i oddanego kobiecie swojego życia.

List jest tekstem o wysokiej użyteczności dla badacza literatury, gdyż jego podstawową cechą jest osadzenie w epoce, w której powstał, nierozerwalne połączenie z ówczesnym światopoglądem, religijnością, stylem literackim czy upodobaniami. Rzeczywistość ta pozostaje historyczna, mimo że autor mógł ją zniekształcić przez swoje subiektywne spojrzenie. Dlatego też Skwarczyńska optuje za badaniem listu osadzonego w epoce, na tle sfery społecznej, kultury ${ }^{42}$. Należy zatem przybliżyć charakter epoki, w której żyli państwo Sobiescy.

Jak podają źródła historyczne, Jan Sobieski urodził się jako drugi syn. Zgodnie z notatką matki, Teofili z Daniłowiczów („Pamięć, iakom ia szła za mąż y iako się moie dzieci rodzili”), Jan przyszedł na świat 17 sierpnia 1629 roku. Sam Sobieski w swojej autobiografii pisze:

${ }^{42}$ Zob. W. Zemek, Listy a literatura: korespondencja Stanisława Lema z Michatem Kandlem, Kraków 2009, s. 8. 
Urodziłem się w Olesku, zamku na wysokiej górze. Podczas mojego urodzenia biły pioruny bardzo, tak że aż krawiec matki mojej od tego oguchł i był głuchym do samej śmierci. Tatarowie też podpadali w tenże czas pod zamek ${ }^{43}$.

Data narodzin Marysieńki nie jest dokładnie znana. Zgodnie z diariuszem najstarszego jej syna Jakuba przyjmuje się, że był to 28 czerwca $1641 \mathrm{roku}^{44}$. Niemniej jednak oboje żyli w wieku XVII, czasie trudnym dla Rzeczypospolitej, w której toczyły się nieustanne wojny. Wystarczy wspomnieć bunt Kozaków pod wodzą Chmielnickiego, potop szwedzki, czy rokosz Lubomirskiego. Jednak XVII wiek to przede wszystkim czas baroku, któremu towarzyszyło szybkie rozprzestrzenianie się idei sarmatyzmu. Głosiła ona wyjątkowe powołanie szlachty, jednoczyła przedstawicieli tego stanu z ziem polskich, litewskich i ruskich, umacniając jednocześnie Rzeczpospolitą Obojga Narodów i dając jej prawo do pozycji mocarstwa. Katolicyzm był sarmacką religią panującą, co w dobie reformacji i kontrreformacji wywoływało silne emocje $e^{45}$. Nic dziwnego, że Sobieski, wychowany przez matkę spartankę w kulcie ojczyzny i honoru, pozostał wierny sarmackim ideałom. Także jego listy nosiły znamiona epoki i ówczesnego światopoglądu - wiara w Boga przeplata się z intensywną sensualnością, a tej z kolei towarzyszą wątki seksualne, cielesne. Sobieski przy jakże barokowej tematyce zachowuje swoją urzekającą bezpośredniość. Zdaje się, że tabu dla niego niemalże nie istniało.

Temat ten szeroko omawia Iwona Maciejewska w artykule Erotyka jako temat wyznań w barokowym liście miłosnym. Próby przełamywania tabu. Zwraca ona uwagę, że w każdej kulturze istnieją pewne sfery obwarowane tabu. Seksualność człowieka objęta jest owym tabu niemalże na całym świecie, a razem z nią pojawia się zakaz wymawiania pewnych wyrazów. Jeśli prześledzimy listy Sobieskiego pod kątem erotyzmu i sposobu pisania o nim, zauważymy, że w pewnym sensie stosuje

\footnotetext{
${ }^{43}$ T. Boy-Żeleński, Marysieńka Sobieska, s. 26.

${ }^{44}$ Zob. T. Boy-Żeleński, Marysieńka Sobieska, s. 36.

${ }^{45}$ Zob. Historia, red. A. Friszke, E. Król, Warszawa 2004, s. 62-64, 822-823.
} 
się do tabu, pozostając jednak na swój sposób bezpośredni i wyzwolony od ograniczeń społeczno-kulturowych.

Lekarstwa i te wody, którycheć Wć zażywać poczęła, niesłychanie mię trapią. Wniwecz Wci, moja duszo, żołądek zepsują i zaziębią. Wspomnisz Wć moje słowo: po chwili i smaku i chęci nie będzie douczyń tę r z e cz [wyróżnienie - W. K.], tak Wć tym rozziębią ${ }^{46}$.

Sobieski zdaje się całkiem swobodnie pisać o seksualności. Mimo to nie wyraża się wprost, a do eufemizowania stosunku płciowego wykorzystuje „bardzo nieprecyzyjne pod względem znaczenia rzeczowniki, zaimki i czasowniki, np. „wszystko”, „to”, „te sprawy”, „te rzeczy”, „coś (konkretnego)”, „,coś więcej”, „coś z kimś”47. Charakterystyczne dla epistolografii Sobieskiego są ustępy wspomnień intymnego pożycia z ukochaną Marysieńką - Sylwander często ucieka się do miejsc spotkań z Bukietem, przywołuje zachowania swojej Francuzki. W liście z Pielaskowic datowanym na 9 września 1666 roku Sobieski pisze:

Pierwsza owa szczęśliwa pod Czerskiem stodoła, gdzie ledwie nie konano, na dni tylko kilka rozjeżdżając się ze swoim Sylwandrem; nuż żółkiewska stodoła; nóż owa w Chmielu, w której jakie protestacje, jakie lamenty, że i dnia wytrwać nie możono, gdzie momenty zdały się wiekami (...).

Stomma uzupełnia ów fragment swoim komentarzem, bo przecież „wolelibyśmy, żeby chodziło faktycznie o stodoły. Niestety, Sobieski używa tego słowa również na określenie podłych zajazdów" ${ }^{48}$. Potrzeba bli-

\footnotetext{
${ }^{46}$ J. Sobieski, Listy do Marysieńki, s. 62.

${ }^{47}$ I. Maciejewska, Erotyka jako temat wyznań w barokowym liście miłosnym. Próby przełamywania tabu, „Napis. Pismo poświęcone literaturze okolicznościowej i użytkowej” 18 (2012), s. 7. Cyt. za: A. Dąbrowska, Eufemizmy wspótczesnego języka polskiego, Wrocław 2009, s. 247-248.

${ }^{48}$ L. Stomma, Życie seksualne..., s. 66.
} 
skości z ukochaną Marysieńką jest u Sobieskiego bardzo silna, jakby to właśnie przy niej było jego locus amoenus. Zdają się nie przeszkadzać mu owe „podłe zajazdy”. Co więcej, rozmiłowany we „wszystkich ślicznościach najwdzięczniejszej Jutrzenki"49 - dostrzega pewien urok w podrzędnych karczmach, czuje się z nimi emocjonalnie związany jako ze świadkami i towarzyszami jego najszczęśliwszych chwil.

Król Jan nieustannie wraca myślami do erotycznych uniesień przeżytych z Marysieńką i opisuje je w listach. Podczas rozłąki - licznych kampanii wojennych Sobieskiego i długich pobytów pani Janowej Sobieskiej w Paryżu - jest to sposób na utrzymanie intymnej więzi z ukochaną. Widać jednak, że nieustanna absencja seksualna daje się mu we znaki. "Co strony szylwachta, lubo go już i postem morzę, co samemu bardzo szkodzi pryncypałowi, nic mu to przecię nie pomaga. Wytrwać dłużej niepodobna"50. Nieustannie kluczy między niedomówieniami, zmaga się z tabu i wychodzi z tych zmagań obronną ręką.

Sobieski nie ogranicza się jednak tylko do swojej cielesności - bez ogródek pyta małżonkę, czy jest równie spragniona bliskości, co on. W liście z Nożyczyna (17 lipca 1666 roku) znajduje się niniejszy ustęp: „(...) luboć i w łóżku niewielka pociecha bez ślicznej muszeczki, bez której już tak tęskno i niezdrowo, że aż się coś dziwnego dzieje człowiekowi. Jeśli toż po sobie wdzięczny czuje Bukiet, proszę oznajmić" ${ }^{51}$. Rok później w jednym z listów pisze: „Cyceczki i brzuszek jak się mają, oznajmij moja panno Sylwandrowi”52. Czym są muszeczka i wspomniany w uprzednio cytowanym liście szylwacht? Stomma pisze tylko, że „nie będziemy przez skromność tłumaczyć. Domyślić się wszakże nie aż tak bardzo trudno" ${ }^{53}$. Maciejewska doprecyzowuje, tłumacząc za Dąbrowską, że określeń oznaczających męskie i żeńskie narządy płciowe było i jest

\footnotetext{
${ }^{49}$ J. Sobieski, Listy do Marysieńki, s. 186.

${ }^{50}$ J. Sobieski, Listy do Marysieńki, s. 270. Cyt. za: L. Stomma, Życie seksualne..., s. 67.

${ }^{51}$ J. Sobieski, Listy do Marysieńki, s. 142.

${ }^{52}$ J. Sobieski, Listy do Marysieńki, s. 234.

${ }^{53}$ L. Stomma, Życie seksualne..., s. 69.
} 
bardzo wiele ${ }^{54}$; także w epistolografii króla. Sobieski bowiem nie ogranicza się, jest na wskroś bezpośredni, cielesność nie jest mu obca, a wręcz przeciwnie - chętnie sięga do intymnych wynurzeń. Żył wszak w epoce baroku, kiedy w sztuce nastąpiło silne ukierunkowanie na erotyczność, nierzadko połączoną z religijnością (czego przykładem może być poezja światowych rozkoszy). Miłość barokowa to przede wszystkim gwałtowność, pożądanie, sensualność. Artyści coraz odważniej zaczęli operować nagością, pod osłoną scen alegorycznych przemycali motywy erotyczne. Ponadto człowiek baroku miał niezwykle silne poczucie kruchości życia, dostrzegał swą marność, dlatego istotnym stało się korzystanie z uroków świata. Nie zapominano jednak o Bogu, który ów rozkoszny świat stworzył. Zważywszy na to, charakter epistolografii Sobieskiego jest całkowicie zrozumiały.

Jego listy ze względu na tematykę utrzymane są w konwencji listu barokowego. Styl jednak pozostaje prosty, brak mu barokowej ciężkości, łacińskich makaronizmów, przepychu i poetyckości. Można by rzec, że łączy on tematykę barokową ze stylem rokokowym. „W pasterskiej metaforyce listów do Marysieńki, w rokokowej stylistyce tego dialogu wzorowanego na romansowej literaturze ujawnia się dworna edukacja króla Jana"55 - mówi o Sobieskim Czesław Hernas. Wydaje się, że owa rokokowa stylistyka jest najbardziej naturalną dla króla epistolografa, który swoje duchowe wychowanie odebrał z francuskich romansów powstających w państwie będącym kolebką rokoka. Styl ten utożsamiany jest ze schyłkiem baroku - cechuje go większa zwiewność, delikatniejsze zdobienia. Określany jest także mianem stylu dworskiego, gdyż swoje źródło ma na dworze królewskim Ludwika $\mathrm{XV}^{56}$.

Niewątpliwie do rokokowego charakteru listów Sobieskiego przyczyniła się lektura romansów francuskich, takich jak Atramene ou le Grand Cyrus autorstwa panny de Scudery, Cleopatre pióra La Calprenede'a, a przede wszystkim romansu pasterskiego Honoriusza d'Urfe L'Astree,

\footnotetext{
${ }^{54}$ Zob. I. Maciejewska, Erotyka jako temat..., s. 9.

${ }^{55}$ C. Hernas, Barok, s. 439.

${ }^{56}$ Zob. Historia, red. A. Friszke, E. Król, s. 782-783.
} 
którego świeża lektura znajduje swój wyraz w pseudonimach używanych przez Sobieskich ${ }^{57}$. Maria Kazimiera przyjmuje imię pięknej pasterki Astrei, Sobieski zostaje wiernym, uwielbiającym ją Celadonem. Równolegle w romansie Honoriusza toczy się wątek miłosny Diany i Sylwandra. Zauroczony bardziej Marysieńką niż polecaną przez nią lekturą - Sobieski stara się wejść w rolę pokornego Sylwandra. „Astrea stała się brewiarzem dworzanina doskonałego: wpajała weń grzeczność i dyskrecję, kazała mu cenić elegancję i konwenans w słowach i w postępowaniu, zachęcała do troski o honor i dobrą sławę"58.

Tak więc Sobieski dał się porwać dworskim romansom, a przede wszystkim pozwolił zawładnąć sobą kapryśnej Astrei. Dla niej barwił swe listy francuszczyzną, dla jej szczęścia robił wszystko, by czuła się jak w ojczyźnie. Ona pisywała do niego tylko w języku francuskim, on używał go wtedy, gdy wymagał tego temat - uwznioślone uczucie prezentowało się o wiele lepiej w języku Astrei. Różna była też kultura miłosna w Rzeczypospolitej oraz we Francji.

Istotnie przepaść dzieliła kulturę miłosną francuską a polską po wiek XVIII. Francuska miała za sobą w średniowieczu kult damy serca, błędne rycerstwo i poezję trubadurów, a potem potęgę salonu, w którym królowała kobieta stwarzająca dla potrzeb miłości nie tylko sztukę, ale nawet specjalny język, styl. (...) Kobieta była panią i prawodawczynią wyższego życia ${ }^{59}$.

A co z ojczystą kulturą miłosną? Skwarczyńska zauważa, że „[w] Polsce nie istniała odrębna kultura miłosna. (...) Kobieta polska nie brała udziału w życiu towarzyskiem” ${ }^{60}$. Cóż zatem dziwnego, że Sobieski wy-

${ }^{57}$ Zob. L. Kukulski, Sobieski epistolograf, w: Literatura, komparatystyka, folklor. Księga poświęcona Julianowi Krzyżanowskiemu, red. M. Bokszczanin, S. Frybes, E. Jankowski, Warszawa 1968, s. 207.

${ }^{58}$ L. Kukulski, Listy do Jana Sobieskiego, Warszawa 1966, s. 94.

59 S. Skwarczyńska, Listy Sobieskiego..., s. 39.

${ }^{60}$ S. Skwarczyńska, Listy Sobieskiego..., s. 39. 
trwale korzystał z wzorców francuskich, skoro jego ojczyzna nie zdążyła jeszcze wytworzyć własnej kultury miłosnej. Poza tym Sobieski, zakochując się we Francuzce, musiał przyjąć jej kulturę miłosną, co jest umotywowane psychologicznie chęcią przypodobania się Marysieńce ${ }^{61}$.

Czytając list datowany na 16 listopada 1667 roku, pisany z obozu, czuć ową francuską nutę zrozpaczonego kochanka, który czeka na choć jeden przychylny gest pani swego serca. „Bądź tylko zdrowa, moja Marysieńku, i kochaj dziesiątą część tego przynajmniej, jako cię kocha twój najwierniejszy Sylvandre"62.

Sobieski nie przejął jednak tylko owej inwersji miłosnej ${ }^{63}$, a przede wszystkim język francuski, który służy mu nie tylko uwzniośleniu miłości, ale także stanowi element szyfru, zabezpieczenia, ukrycia się. Ten niepoprawny Sarmata nieustannie nawiązuje do seksualności, erotyzmu, a francuszczyzna (oprócz wyżej przedstawionych eufemizmów) idealnie „maskuje” jego myśl. „Myśląc o Tobie, zdarza się często, że szylwacht (...) czyni tę rzecz, która nie jest dobra dla jego zdrowia (...) a co gorsze grzeszna" ${ }^{64}$. Sobieski ucieka się do charakterystycznych dla jego stylu określeń. Okazuje się jednak, że tym razem stosuje podwójny, a nawet potrójny kamuflaż. Pisząc najprawdopodobniej o onanizmie, dokonuje obszernej charakterystyki czynności jako niezdrowej, a także grzesznej. Ponadto cały powyższy ustęp zapisuje francuszczyzną ${ }^{65}$. Nawet jednak pisując po francusku, Sobieski pozostaje na wskroś bezpośredni. W słowach prostych, zrozumiałych wyraża nie tylko treści związane z fizycznością, ale także z duchowością i sferą sacrum.

Na koniec warto przyjrzeć się także historycznym zmianom konwencji epistolograficznych. Kolejno powstawały koncepcje „listu-mowy”, „listu-półdialogu”, „listu-wyznania” i „listu bez reguł”66. Choć

61 Zob. S. Skwarczyńska, Listy Sobieskiego..., s. 39.

${ }^{62}$ J. Sobieski, Listy do Marysieńki, s. 234.

${ }^{63}$ Zob. S. Skwarczyńska, Listy Sobieskiego..., s. 38-48, 71-75.

${ }^{64}$ L. Stomma, Życie seksualne..., s. 67. Fragment ten cytuję za Ludwikiem Stommą, gdyż w Listach do Marysieńki nie zostało podane polskie tłumaczenie francuskiej frazy.

${ }^{65}$ Zob. I. Maciejewska, Erotyka jako temat..., s. 9.

${ }^{66}$ Zob. S. Skwarczyńska, Teoria listu, s. 21-37. 
aż do XVIII wieku powszechnie obowiązywała opisowo-normatywna teoria listu, a „list-wyznanie” wprowadza dopiero sentymentalizm wraz z wybuchem uczuciowości ${ }^{67}$, wydaje się jednak, że Sobieski, czerpiąc z francuskiej kultury miłosnej, przyspieszył rozwój wydarzeń. Jego korespondencja do Marysieńki nosi bowiem znamiona wyznania. Młody Sobieski, zapalny jak proch ${ }^{68}$, podąża za Sylwandrem, kreując swe listy na gorące wyznania: „Bądź zdrowa, moje serce. Całuję cię milion razy; jestem i pozostanę zawsze ten sam" ${ }^{\text {"9 }}$. Sobieski niekwestionowanie był absolutnym mistrzem deklaracji uczuć. Ileż razy musiał przełknąć gorycz oskarżeń Marysieńki o zdradę bądź odmianę serca, ileż razy musiał natychmiast zapewniać o stałości, wierności, dozgonnym uwielbieniu i miłości!

Konwencja „listu-wyznania” miesza się jednak z popularną i wciąż wzorcową wówczas teorią listu opisowo-normatywnego. Po trosze również taki charakter mają epistoły Sobieskiego, co niewątpliwie uwarunkowane jest okolicznościami, w jakich znajduje się epistolograf, pisząc do ukochanej. Sobieski nieustannie jest w obozie, cały czas toczy się kampania wojenna, a on - najpierw jako hetman, później jako król jest odpowiedzialny za jej przebieg. Informuje zatem Marysieńkę o bitwach, które stoczyli, pisze o tym, co dzieje się w obozie, opisuje stan swego zdrowia czy - znacznie później - posyła wieści o dokonaniach królewicza Jakuba.

Korespondencja Sobieskich jest także fenomenalnym źródłem badań nad mechanizmami politycznymi funkcjonującymi w siedemnastowiecznej Europie. Jak zauważa Roman Pollak: „List jest swoistym przejawem piśmiennictwa zależnym bardziej niż inne kształty słowa pismem utrwalonego od potrzeb chwili, od warunków współczesnego życia"70. I ta cecha listu jest doskonale widoczna w korespondencji Sobieskich. Jan regularnie donosi małżonce o bieżących wydarzeniach - nie tyl-

${ }^{67}$ Zob. W. Zemek, Listy a literatura..., s. 9.

68 "La Poudre” (proch) to jeden z pseudonimów Jana Sobieskiego.

${ }^{69}$ J. Sobieski, Listy do Marysieńki, s. 46.

${ }^{70}$ Listy Krzysztofa Opalińskiego do brata Łukasza, red. R. Pollak, Wrocław 1957, s. 5. 
ko prywatnych, ale także społeczno-politycznych oraz militarnych. Najpopularniejszy ustęp z całego zbioru Listów do Marysieńki to początek epistoły pisanej tuż po historycznym zwycięstwie pod Wiedniem. „Bóg i Pan nasz na wieki błogosławiony dał zwycięstwo i sławę narodowi naszemu, o jakiej wieki przeszłe nigdy nie słyszały"71 - pisze Sobieski 13 września 1683 roku w nocy, tuż po skończonej bitwie.

Listy z obozów mają w sobie coś ze sprawozdania: mąż, punkt po punkcie, spowiada się z przebiegu dnia, nocy... Co ciekawe, nigdy nie łączy miłości z wojną. Oczywiście te dwa tematy są naczelnymi, przewijają się nieustannie, ukazując rytm życia Sobieskiego, mężczyzny rozerwanego między pełną cierpienia miłością a kampanią wojenną, powinnością i honorem szlachcica. Części miłosnej odpowiada „list-wyznanie”, części wojkkowej „list opisowo-normatywny”. W ten sposób Sobieski łączy owe dwie konwencje epistolograficzne, wyrażając swą osobowość, a równocześnie dając świadectwo epoki, w której żyje ${ }^{72}$.

Norbert Korniłłowicz pisze:

\begin{abstract}
Nawet w korespondencji Jana Sobieskiego, naszego „najbardziej erotycznego króla”, w której podmiot mówiący jest wyraźną autokreacją podmiotu piszącego, plany heroiczny i uczuciowy rozwijają się wprawdzie nie przeciwstawnie, ale rozdzielnie. Wojna i miłość układają się w dwa odrębne wątki ${ }^{73}$.
\end{abstract}

Sobieski raczej nie ucieka się do walki dla ukochanej, nie składa wieńców pod jej nogami, nie znosi trudów wojny dla niej. Chyba tylko raz dziękuje Marysieńce za przysłanie szarfy, w której chciał walczyć z wojskami rokoszowymi Lubomirskiego. Nie ma w tym jednak nic dziwnego

${ }^{71}$ J. Sobieski, Listy do Marysieńki, s. 522.

${ }^{72}$ Literatura oraz epistolografia w XVII wieku realizowały zasadę jedności tematu, co znajduje odzwierciedlenie w listach Sobieskiego. Zob. N. Korniłłowicz, Motywy heroizmu i miłości w literaturze polskiej XVII wieku, „Pamiętnik Literacki” 73 (1982) z. 1/2, S. $179-192$.

${ }^{73}$ N. Korniłłowicz, Motywy heroizmu..., s. 188-189. 
- tu znów pobrzmiewają echa lektury francuskich romansów i francuskiej kultury miłosnej ${ }^{74}$. Co do zasady w partiach korespondencji dotyczącej spraw militarnych Sobieski jawi się jako mąż stanu, trzeźwo myślący dowódca i strateg. Prowadzi narrację rzeczową, bez zbędnych frazesów, prawdziwie hetmańską. Natomiast gdy przechodzi do intymnych wynurzeń, staje się czułym kochankiem, pełnym pożądliwości, ale także tęsknoty i galanterii ${ }^{75}$. „Jachniczek” pragnie dzielić się ze swoją Marysieńką wszystkim, każdą sekundą swego życia. Oprócz miłości wiele miejsca zajmuje codzienność, przemyślenia, przygody, spotykające go niesprawiedliwości czy rzewnie wylewane żale.

\section{(...) mimo iż tęsknota serca i zmysłów jest natchnieniem tych listów i daje skrzydła ich językowi, nie sądźmy, aby to były monotonne litanie miłosne. Sobieski pisze w nich żonie o wszystkim: o polityce, której oglądamy tu najsekretniejsze kulisy, często jaskrawy tworzące kontrast z bohaterską fasadą, o życiu obozowym (...). Tak oto w tych listach odbija się najau- tentyczniejsze ówczesne życie polskie, widziane oczami człowieka, który z racji swoich wysokich szarż wszystko znał (...) i o wszystkim mówił swojej Marysieńce tak szczerze jak księdzu na spowiedzi ${ }^{76}$.}

Jak widać, listy Jana Sobieskiego do Marysieńki to dla badacza epistolografii materiał szczególnie ciekawy. Autor utrzymuje swe teksty w konwencji listu miłosnego pisanego przez męża kochanka, w którym jak w kalejdoskopie przesuwają się fragmenty o charakterze barokowym i rokokowym; pojawia się także nowoczesna jak na XVII wiek konwencja wyznania oraz obowiązująca wówczas stylistyka listu opisowo-normatywnego. Sobieski chętnie sięga do tematyki erotycznej, a miłość duchowa, zgodnie z barokowymi ideałami, jest dla niego nierozerwalnie związana z cielesnością. Uczucie do Marysieńki jest motorem

${ }^{74}$ Zob. S. Skwarczyńska, Listy Sobieskiego..., s. 38-48.

${ }^{75}$ Zob. N. Korniłłowicz, Motywy heroizmu..., s. 189.

${ }^{76}$ L. Kukulski, Zamiast wstępu, w: J. Sobieski, Listy do Marysieńki, red. L. Kukulski, Warszawa 1970, s. 7-8. 
napędowym jego życia, sensem egzystencji - wszystko, co czyni, robi dla niej. Nieraz zapewnia ją o gorącej miłości, bez której żyć niepodobna. Nieraz przyrzeka wierność do ostatnich swoich dni. Nieraz w końcu wspomina cudowne chwile spędzone z żoną, na myśl których serce mu drży z żalu, że dawniej namiętne uczucie Marysieńki teraz już ostygło.

Sobieski równie często, co o miłości, pisze o swych codziennych doświadczeniach. Informuje o minionym dniu, planach na najbliższy czas, opisuje niewygody życia obozowego czy trudy walki. Głos hetmana, a później króla odzywa się w nim równie często, co głos kochanka. Sobieski jednak nigdy owych dwóch ról nie łączy w listach. Kiedy jest przywódcą, tekst pozostaje surowy, suchy, zwięzły, kiedy przemienia się w kochanka, przemienia się razem z nim jego język - staje się ciepły, żarliwy, pełen tęsknoty i palącego jego wnętrze uczucia. Epistolograf realizuje staropolską normę każącą wojnę oddzielać od miłości ${ }^{77}$.

Jakikolwiek jednak temat podejmuje Sobieski, zawsze pozostaje na wskroś bezpośredni. Pisze z niezwykłą lekkością - zdaje się, że urodził się z piórem w dłoni. „Ukazuje się jako niepospolity pisarz, znawca maniery romansowej francuskiej”78 - pisze o królu Julian Krzyżanowski. Urodzony epistolograf cechuje się silnym związkiem z życiem, umiejętnością wczuwania się w rolę adresata oraz postawą daleką od skrytości ${ }^{79}$.

Nie ma wątpliwości, że listy Sobieskiego przesycone są życiem. Wszystko, o czym pisze, jest nierozerwalnie związane z jego egzystencją - czy jako namiętnego kochanka Celadona, czy jako odpowiedzialnego przywódcy. Język jego w każdej sytuacji pozostaje swobodny, słowa płyną lekko, zwiewnie. Ponadto dla „Jachniczka” nie ma tematów, których nie wypada poruszyć; polityka, wojskowość, miłość, cielesność, wewnętrzne rozterki i żale - Sobieski pisze o wszystkim i na każdy temat pragnie poznać zdanie małżonki. Bezpośredniość wyrazu zawsze

77 Zob. N. Korniłłowicz, Motywy heroizmu..., s. 188.

${ }^{78}$ J. Krzyżanowski, Historia literatury polskiej, Warszawa 1974, s. 366.

79 Zob. G. Selwach, „Teoria listu”, Stefania Skwarczyńska, na podstawie lwowskiego pierwodruku opracowali Elżbieta Feliksiak i Mariusz Leś, Białystok 2006 : [recenzja], „Pamiętnik Literacki” 101 (2010) z. 2, s. 256. 
triumfuje w jego listach - nic w tym dziwnego, w końcu pisze do swej ukochanej Marysieńki, pani jego serca i duszy, pod nogi której bez wahania rzucił swój los.

Listy Jana III Sobieskiego do Marysieńki są świadectwem życia jednego z najsławniejszych królów Polski. Pokazują kulisy krętej drogi do chwały i uświadamiają, że nie ma rzeczy niemożliwych. Przede wszystkim jednak są wspaniałym dowodem na to, jak jedna miłość może zawładnąć całym życiem i stać się przyczyną wszystkich wydarzeń. Sobieski - król bohater - stał się niezaprzeczalnie jednym z najbardziej rozpoznawalnych kochanków w historii Polski, a jego korespondencja z Marią Kazimierą to najpiękniejszy dowód ich miłości i jej nośnik, który temu niezwykłemu uczuciu zapewnił nieśmiertelność.

\section{EPISTOLOGRAPHY CONVENTION AND DIRECTNESS OF EXPRESSION IN JAN III SOBIESKI'S LETTERS TO MARYSIEŃKA}

\section{SUMMARY}

The article recounts about Jan III Sobieski's epistles from 1655-1683 which were written to his wife Maria Kazimiera d'Arquien. The division of listing's model, which was made by Robert Ganszyniec, and the framing of letters' type according to Stefania Skwarczyńska were taken as a basis in creation of interesting epistolographic convection category typical for Sobieski. Furthermore the text reveals the manner in which Sobieski reaches a directness of the statements as well as the themes which dominate in his letters and the way of taboo implementation. However, the article does not present the letters in detachment with historical and socio-cultural reality. The correspondence of Jan and Maria Sobieski is not only an evidence of great love but also reveals historical events from the participants' perspective with signs of baroque. 
The article includes many citations from epistles written by Jan III Sobieski in order to present the reader the discussed issues sufficiently. It also presents the stand of the most accomplished literary historians such as Stefania Skwarczyńska, Alojzy Sajkowski or Leszek Kukulski.

\section{KEYWORDS}

Jan III Sobieski, Marysieńka, Maria Kazimiera d’Arquien, letters, directness of expression, love letters, king of Poland, baroque, epistolography convention, history of literature, correspondence, literary studies

\section{BIBLIOGRAFIA}

Boy-Żeleński T., Marysieńka Sobieska, Warszawa 1976.

Ganszyniec R., Polskie listy miłosne dawnych czasów, Kraków 1925.

Głowiński M., Kostkiewiczowa T., Okopień-Sławińska A., Sławiński J., Słownik terminów literackich, Wrocław 1982.

Hernas C., Barok, Warszawa 1973.

Historia, red. A. Friszke, E. Król, Warszawa 2004.

Konopczyński W., Od Sobieskiego do Kościuszki, Kraków 1921.

Korniłłowicz N., Motywy heroizmu i miłości w literaturze polskiej XVII wieku, „Pamiętnik Literacki” 73 (1982) z. 1/2.

Krzyżanowski J., Historia literatury polskiej, Warszawa 1974.

Kukulski L., Listy do Jana Sobieskiego, Warszawa 1966.

Kukulski L., Sobieski epistolograf, w: Literatura, komparatystyka, folklor. Ksiega poświęcona Julianowi Krzyżanowskiemu, red. M. Bokszczanin, S. Frybes, E. Jankowski, Warszawa 1968.

Listy Krzysztofa Opalińskiego do brata Łukasza, red. R. Pollak, Wrocław 1957. Maciejewska I., Erotyka jako temat wyznań w barokowym liście mitosnym. Próby przełamywania tabu, „Napis. Pismo poświęcone literaturze okolicznościowej i użytkowej” 18 (2012).

Praktyczny słownik wspótczesnej polszczyzny, t. 11, red. H. Zgółkowa, Poznań 1997.

Ryszkiewicz M., List w „interesownej” i "nieinteresownej” odmianie dzieła literackiego, „Annales UMCS” XXII (2004) sectio FF. 
Sajkowski A., Sarmackie tradycje i europejskie horyzonty, Poznań 2007.

Sajkowski A., Staropolska miłość. Z dawnych listów i pamiętników, Poznań 1981. Selwach G., „Teoria listu”, Stefania Skwarczyńska, na podstawie lwowskiego pierwodruku opracowali Elżbieta Feliksiak i Mariusz Leś, Białystok 2006 : [recenzja], „Pamiętnik Literacki” 101 (2010) z. 2.

Skwarczyńska S., Listy Sobieskiego do Marysieńki jako zjawisko kulturalne i literackie, „Ruch Literacki” 11 (1936).

Skwarczyńska S., Teoria listu, Lwów 1937.

Skwarczyńska S., Wstęp do nauki o literaturze, t. 3, Warszawa 1965.

Sobieski J., Listy do Marysieńki, red. L. Kukulski, Warszawa 1970.

Stomma L., Życie seksualne królów Polski i inne smakowitości, Warszawa 2002. Wiśniewska H., Zachowania grzecznościowe w listach rodzinnych Ignacego Krasickiego, „Pamiętnik Literacki” 91 (200o) z. 3.

Zemek W., Listy a literatura: korespondencja Stanistawa Lema $z$ Michatem Kandlem, Kraków 2009. 